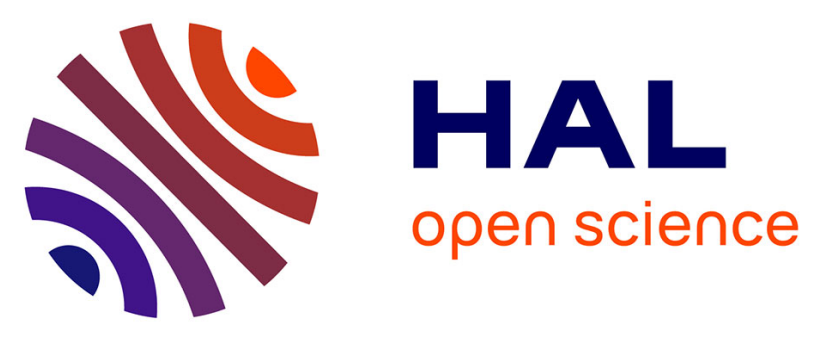

\title{
Surface structure and electrochemical characteristics of plasma-fluorinated petroleum cokes for lithium ion battery
}

Tsuyoshi Nakajima, Seiko Shibata, Kazuhisa Naga, Yoshimi Ohzawa, Alain Tressaud, Etienne Durand, Henri Groult, Fabienne Warmont

\section{To cite this version:}

Tsuyoshi Nakajima, Seiko Shibata, Kazuhisa Naga, Yoshimi Ohzawa, Alain Tressaud, et al.. Surface structure and electrochemical characteristics of plasma-fluorinated petroleum cokes for lithium ion battery. Journal of Power Sources, 2007, 168 (1), pp.265-271. 10.1016/j.jpowsour.2007.03.008 . hal00150404

\section{HAL Id: hal-00150404 \\ https://hal.science/hal-00150404}

Submitted on 28 Oct 2021

HAL is a multi-disciplinary open access archive for the deposit and dissemination of scientific research documents, whether they are published or not. The documents may come from teaching and research institutions in France or abroad, or from public or private research centers.
L'archive ouverte pluridisciplinaire HAL, est destinée au dépôt et à la diffusion de documents scientifiques de niveau recherche, publiés ou non, émanant des établissements d'enseignement et de recherche français ou étrangers, des laboratoires publics ou privés. 


\title{
Surface structure and electrochemical characteristics of plasma-fluorinated petroleum cokes for lithium ion battery
}

\author{
Tsuyoshi Nakajima ${ }^{a}, *$, Seiko Shibata ${ }^{a}, K^{2}$ azuhisa Naga a, Yoshimi Ohzawa ${ }^{a}$, \\ Alain Tressaud ${ }^{\mathrm{b}}$, Etienne Durand ${ }^{\mathrm{b}}$, Henri Groult ${ }^{\mathrm{c}}$, Fabienne Warmont $^{\mathrm{d}}$ \\ a Department of Applied Chemistry, Aichi Institute of Technology, Yakusa, Toyota 470-0392, Japan \\ b ICMCB-CNRS, Université Bordeaux I, 87 Ave. Dr A. Schweitzer, 33608 Pessac, France \\ ${ }^{\mathrm{c}}$ Université Pierre et Marie Curie-Paris6, CNRS-UPMC-ESPCI UMR 7612, Laboratoire LI2C, 4 Place Jussieu, Paris F-75005, France \\ d CMRD-UMR 6619, CNRS, Orleans, France
}

\begin{abstract}
Plasma-fluorination of petroleum coke and those heat-treated at 1860, 2300 and $2800{ }^{\circ} \mathrm{C}$ (abbreviated to PC, $\mathrm{PC} 1860, \mathrm{PC} 2300$ and $\mathrm{PC} 2800$ ) was conducted for 15,30 and $60 \mathrm{~min}$ using $\mathrm{CF}_{4}$ gas at $90^{\circ} \mathrm{C}$. Fluorine contents obtained by elemental analysis were negligible except PC fluorinated for $60 \mathrm{~min}(0.7$ at.\%). Fluorine concentration on the surface decreased with increasing heat-treatment temperature of petroleum coke, i.e. from PC to PC2800 when plasma-fluorination was made for 30 and $60 \mathrm{~min}$. Transmission electron microscopic observation revealed that the closed edges of PC2800 were destroyed and opened by plasma-treatment. Plasma-fluorination increased surface disorder of heat-treated petroleum cokes, however, slightly reduced surface areas. These surface structure changes increased first coulombic efficiencies of PC 2300 and PC2800 by 6-8 and $8-10 \%$ at both 60 and $150 \mathrm{~mA} \mathrm{~g}^{-1}$, respectively.
\end{abstract}

Keywords: Plasma-fluorination; Surface modification; Carbon anode; Lithium ion battery

\section{Introduction}

Graphite is mainly used as anode of lithium ion battery because of its low potential, high coulombic efficiency (low irreversible capacity) and constant reversible capacity. Surface structure is one of the important factors influencing the electrode characteristics of carbonaceous anodes. Since carbon material has an anisotropic layered structure, surface edge structure and surface chemical species would give large effects to the electrode performance. Some methods of surface modification have been applied to carbon anode materials to improve their anode characteristics [1-5]. They include carbon coating [6-14], metal or metal oxide coating [15-21], surface oxidation [22-29], surface fluorination [30-40] and polymer or Si coating [41-47]. Carbon coating is a good method to improve electrode performance, in particular to reduce irreversible capacities [6-14].

\footnotetext{
* Corresponding author. Tel.: +81 56548 8121x2201; fax: +81 565480076 . E-mail address: nakajima-san@aitech.ac.jp (T. Nakajima).
}

Mild oxidation increases the capacities in some cases, however, strong oxidation degrades carbon materials [22-29]. Surface fluorination is effective for improving electrode characteristics of graphitic materials [30-40]. Light fluorination of natural graphite samples (average diameter: 7, 25 and $40 \mu \mathrm{m}$; BET surface area: $4.8,3.4$ and $2.7 \mathrm{~m}^{2} \mathrm{~g}^{-1}$ ) by $\mathrm{F}_{2}$ gave the higher capacities of $380-390 \mathrm{mAh} \mathrm{g}^{-1}$ than the theoretical value of graphite, $372 \mathrm{mAh} \mathrm{g}^{-1}$ at $60 \mathrm{~mA} \mathrm{~g}^{-1}$ [30-35]. Surface fluorination of graphitized petroleum cokes by $\mathrm{F}_{2}$ and $\mathrm{ClF}_{3} / \mathrm{NF}_{3}$ highly increased their first coulombic efficiencies and first charge capacities, respectively [37-39].

Natural graphite powder is prepared by pulverization of block or flak graphite and sieving of pulverized mixtures with various particle sizes. The edge surface of powdery natural graphite is therefore opened though some carbon atoms may be terminated by oxygen. On the other hand, synthetic graphite is prepared by heat-treatment of a graphitizing carbon at high temperatures such as $2800-3000^{\circ} \mathrm{C}$. Surface edge structure can be therefore modified during the graphitization process. It was recently reported that surface structure of oxygen containing 
carbon changed during the heat-treatment at high temperatures. Surface-oxidized carbon fiber gave closed edge plane by the heat-treatment at $3000^{\circ} \mathrm{C}$ [48]. Petroleum coke is one of good examples as a starting carbon for preparing synthetic graphite. Heat-treatment of oxygen containing petroleum coke at $2800^{\circ} \mathrm{C}$ also gave rise to the closed edge plane by carbon-carbon bond formation $[39,40]$. The closure of edge surface was confirmed by transmission electron microscopic observation $[39,40]$. Since heat-treatment of a graphitizing carbon is made in a reduced atmosphere, surface oxygen would be eliminated as $\mathrm{CO}$, accompanying carbon-carbon bond breaking. Graphene layers are connected with each other at the edge by the recombination of bare carbon atoms, giving the closed edge plane with round shape. Electrochemical reduction of a solvent and subsequent formation of surface film (solid electrolyte interphase or interface: SEI) may be difficult on such closed edge plane. The SEI formation probably needs the decomposition of a large amount of a solvent such as ethylene carbonate (EC). In fact, first coulombic efficiencies of petroleum cokes heat-treated at $1860-2800^{\circ} \mathrm{C}$ decreased with increasing heat-treatment temperature [37-39]. This is attributed to the effect of closure of edge plane by carbon-carbon bond formation. Light fluorination of graphitized petroleum cokes by $\mathrm{F}_{2}$ destroyed and opened the closed edge plane, increasing their first coulombic efficiencies, i.e. reducing the irreversible capacities [37-39]. On the other hand, fluorination of petroleum cokes by $\mathrm{ClF}_{3}$ and $\mathrm{NF}_{3}$ gave quite different results from those obtained by the fluorination using $\mathrm{F}_{2}$ [40]. Main effect obtained by the fluorination with $\mathrm{ClF}_{3}$ and $\mathrm{NF}_{3}$ was increase in first charge capacities of heat-treated petroleum cokes [40]. It was found that the fluorination reactions of carbon materials with $\mathrm{ClF}_{3}$ and $\mathrm{NF}_{3}$ are radical reactions while the fluorination with $\mathrm{F}_{2}$ is an electrophilic reaction, yielding surface fluorinated layers with high disorder. In the present study, we have applied plasma-fluorination technique to the surface modification of petroleum cokes as examples of synthetic graphites and evaluated the effect of plasmatreatment on their electrode characteristics in comparison with the results previously obtained by the fluorination with $\mathrm{F}_{2}$ and $\mathrm{ClF}_{3} / \mathrm{NF}_{3}$.

\section{Experimental}

\subsection{Plasma-fluorination and analyses of petroleum cokes}

Petroleum coke and those heat-treated at 1860, 2300 and $2800^{\circ} \mathrm{C}$ (abbreviated to PC, PC1860, PC2300 and PC2800) were used as starting carbon materials. The interlayer spacings of their ( $\left.\begin{array}{ll}0 & 0\end{array}\right)$ diffraction lines were $0.3450,0.3385,0.3366$ and $0.3361 \mathrm{~nm}$ for PC, PC1860, PC2300 and PC2800, respectively [37-40]. Petroleum coke sample was placed in the center of the chamber on the electrode connected to rf. Plasma-fluorination of these petroleum coke samples was made using $\mathrm{CF}_{4}$ gas under the following conditions: $\mathrm{CF}_{4}$ flow rate, $8 \mathrm{~cm}^{3} \mathrm{~min}^{-1}$; total gas pressure, 5.0 $\mathrm{Pa}$; power, $80 \mathrm{~W}$; plasma frequency, $13.56 \mathrm{MHz}$; sample temperature, $90^{\circ} \mathrm{C}$ and plasma-treatment time, 15,30 and $60 \mathrm{~min}$. The $d\left(\begin{array}{ll}0 & 02\end{array}\right)$ values of petroleum cokes were nearly the same before and after the plasma-fluorination. The composi- tion and surface structure change were investigated by elemental analysis, X-ray photoelectron spectroscopy (XPS), transmission electron microscopy (TEM), Raman spectroscopy and BET surface area measurements using nitrogen gas.

\subsection{Electrochemical measurements of plasma-fluorinated petroleum cokes}

Electrochemical characteristics of plasma-fluorinated petroleum coke samples were evaluated by cyclic voltammetry and galvanostatic charge/discharge cycling using a threeelectrode cell with lithium counter and reference electrodes in $1 \mathrm{~mol} \mathrm{dm}^{-3} \mathrm{LiClO}_{4}$ ethylene carbonate/diethyl carbonate (DEC) (1:1 in volume). Petroleum coke electrode was prepared as follows. Petroleum coke sample was dispersed in $\mathrm{N}$-methyl2-pyrrolidone (NMP) containing $12 \mathrm{wt} \%$ poly(vinylidene fluoride) (PVdF) and pasted on a foamed nickel. The electrode was dried at $120^{\circ} \mathrm{C}$ under vacuum overnight and pressed before electrochemical measurement. Prepared electrode consisted of $80 \mathrm{wt} . \%$ of petroleum coke sample and $20 \mathrm{wt} . \%$ PVdF. Potential scan rate was $1 \mathrm{mV} \mathrm{s}^{-1}$ for cyclic voltammetry and current densities were 60 and $150 \mathrm{~mA} \mathrm{~g}^{-1}$ for galvanostatic charge/discharge cycling. The electrochemical measurements were performed between 0 and $3 \mathrm{~V}$ versus $\mathrm{Li} / \mathrm{Li}^{+}$at $25^{\circ} \mathrm{C}$ in a glove box filled by Ar.

\section{Results and discussion}

\subsection{Composition and surface structure change of petroleum cokes by plasma-fluorination}

The composition of petroleum cokes obtained by elemental analysis is given in Table 1. Original PC contained 2.9 at.\% of hydrogen, which suggests that PC contains a small amount of oxygen as $-\mathrm{COH}$ and $-\mathrm{CO}(\mathrm{OH})$ [37]. The existence of sur-

Table 1

Composition of plasma-fluorinated petroleum cokes, obtained by elemental analysis

\begin{tabular}{lllll}
\hline Fluorination time (min) & Sample & \multicolumn{3}{l}{ Composition (at.\%) } \\
\cline { 2 - 5 } & & C & F & O \\
\hline \multirow{2}{*}{0} & PC & 94.8 & - & $(2.3)$ \\
& PC1860 & 99.4 & - & $(0.6)$ \\
& PC2300 & 100.0 & - & $(0.0)$ \\
& PC2800 & 100.0 & - & $(0.0)$ \\
\multirow{4}{*}{30} & PC1860 & 100.0 & 0.0 & $(0.0)$ \\
& PC2300 & 100.0 & 0.0 & $(0.0)$ \\
& PC2800 & 100.0 & 0.0 & $(0.0)$ \\
& PC1860 & 100.0 & 0.0 & $(0.0)$ \\
& PC2300 & 100.0 & 0.0 & $(0.0)$ \\
& PC2800 & 100.0 & 0.0 & $(0.0)$ \\
& PC & 96.5 & 0.7 & $(2.8)$ \\
& PC1860 & 100.0 & 0.0 & $(0.0)$ \\
& PC2300 & 100.0 & 0.0 & $(0.0)$ \\
& PC2800 & 100.0 & 0.0 & $(0.0)$ \\
\hline
\end{tabular}

Original PC contained 2.9 at.\% of $\mathrm{H}$. The parenthetical values are estimated value. 
Table 2

Surface composition of plasma-fluorinated petroleum cokes, obtained by XPS

\begin{tabular}{llllr}
\hline \multirow{2}{*}{ Fluorination time (min) } & Sample & \multicolumn{3}{l}{ Surface composition (at.\%) } \\
\cline { 3 - 5 } & & C & F & O \\
\hline 0 & PC & 87.8 & - & 12.2 \\
& PC1860 & 91.7 & - & 8.3 \\
& PC2300 & 92.4 & - & 7.6 \\
& PC2800 & 93.4 & - & 6.6 \\
\multirow{4}{*}{35} & PC1860 & 86.9 & 1.5 & 11.6 \\
& PC2300 & 85.5 & 4.1 & 10.4 \\
& PC2800 & 81.3 & 8.1 & 10.6 \\
& PC1860 & 80.1 & 12.4 & 7.5 \\
60 & PC2300 & 81.7 & 10.4 & 7.9 \\
& PC2800 & 84.4 & 6.5 & 9.1 \\
& PC & 54.2 & 35.7 & 10.1 \\
& PC1860 & 74.3 & 15.8 & 9.9 \\
& PC2300 & 77.2 & 12.0 & 10.8 \\
& PC2800 & 83.2 & 7.4 & 9.4 \\
\hline
\end{tabular}

face oxygen was shown by O1s XPS spectra as mentioned later. The fluorine contents were negligible except PC fluorinated for $60 \mathrm{~min}(0.7$ at.\%), being very different from those detected for the same petroleum cokes fluorinated by $\mathrm{F}_{2}[37,38]$. Table 2 shows the surface composition of petroleum coke samples, obtained by XPS. The fluorine concentration on the surface increased with increasing plasma-treatment time. At the beginning of plasma-fluorination (15 min-treatment), surface disordered parts were probably removed as fluorocarbon gases because the surface fluorine concentration became lower in the order of PC2800, PC2300 and PC1860. When plasma-treatment time was extended to 30 and $60 \mathrm{~min}$, the surface fluorine concentration decreased with increasing heat-treatment temperature of petroleum coke from PC1860 or PC to PC2800. Petroleum cokes graphitized at the higher temperatures are more stable against fluorination. As already shown in a previous paper [39], the edge of oxygen containing petroleum coke is closed by carbon-carbon bond formation during the graphitization process at high temperatures of $2300-2800{ }^{\circ} \mathrm{C}$. The closure of edge plane would occur by the elimination of surface oxygen as $\mathrm{CO}$ and recombination of bare carbon atoms. For this reason, the closed edge plane may be more stable also against plasma-treatment. This would be the reason why the surface fluorine concentration decreased with increasing graphitization temperature of petroleum coke, i.e. from PC1860 or PC to PC2800. The fluorine contents in Table 1 were lower than the values of $0.3-1.7$ at.\% obtained when the same petroleum cokes were fluorinated by $\mathrm{F}_{2}$ $[37,38]$. The surface fluorine concentrations obtained for $60 \mathrm{~min}-$ treated samples in Table 2 were, however, close to those for the petroleum cokes fluorinated by $\mathrm{F}_{2}$ at $300^{\circ} \mathrm{C}[37,38]$. It means that only surface layers of petroleum cokes were fluorinated by plasma-fluorination. On the other hand, no surface fluorine was found except one sample when the petroleum cokes were fluorinated by $\mathrm{ClF}_{3}$ and $\mathrm{NF}_{3}$ at $200-500{ }^{\circ} \mathrm{C}$ [40]. It is known that fluorination of organic compounds and carbon materials by $\mathrm{F}_{2}$ is an electrophilic reaction, that is, $\mathrm{F}^{\delta+}$ preferentially attacks $\mathrm{C}^{\delta-}$ having a high electron density and $\mathrm{F}^{\delta-}$ is bonded to another ele- ment with a low electron density, yielding fluorinated graphene layers [49-51]. However, radical species such as $\mathrm{CF}_{3}$ attack carbon atoms in plasma-fluorination using $\mathrm{CF}_{4}$. Atoms and radicals such as $\mathrm{F}, \mathrm{Cl}, \mathrm{ClF}_{2}$ and $\mathrm{NF}_{2}$ generated by thermal decomposition of $\mathrm{ClF}_{3}$ and $\mathrm{NF}_{3}$ react with carbons in the fluorination using $\mathrm{ClF}_{3}$ and $\mathrm{NF}_{3}$ [40]. In such radical reactions, surface etching of carbon materials occurs, yielding fluorocarbon gases. Plasma-fluorination has the similar surface etching effect to that observed for the fluorination by $\mathrm{ClF}_{3}$ and $\mathrm{NF}_{3}$ at high temperatures. However, surface fluorine concentrations were much higher in the plasma-fluorination than in the fluorination by $\mathrm{ClF}_{3}$ and $\mathrm{NF}_{3}$. This may be ascribed to the low temperature of plasmafluorination. The sample temperature was $90^{\circ} \mathrm{C}$ in the case of plasma-fluorination while the fluorination with $\mathrm{ClF}_{3}$ and $\mathrm{NF}_{3}$ was done between 200 and $500^{\circ} \mathrm{C}$. The difference in the fluorine contents and surface fluorine concentrations due to the fluorination methods are thus attributed to the difference in the reaction mechanisms and temperatures. Surface oxygen was detected in all samples as given in Table 2. The surface oxygen concentrations were not largely changed before and after plasmafluorination.

TEM observation was performed to confirm the surface structure change of graphitized petroleum cokes by plasmafluorination. Fig. 1 shows TEM images obtained for PC2800 and those plasma-fluorinated for 15 and $60 \mathrm{~min}$. The closed edges of non-fluorinated PC2800 are seen in Fig. 1(a), being formed by carbon-carbon bond formation with elimination of surface oxygen as $\mathrm{CO}$ during heat-treatment. The closed edges were observed in every part of the edge plane of PC2800. The same closed edges were also found in PC2300. It is seen in Fig. 1(b) that the closed edges were removed by surface etching. In PC2800 plasma-fluorinated for $60 \mathrm{~min}$ (Fig. 1(c)), the top of closed edges were destroyed and opened though closed edges were still observed. When plasma-fluorination of petroleum coke was made, a powder petroleum coke sample was placed in the center of the chamber. Therefore, plasma-treatment was not uniformly done to the surface of petroleum coke sample. In addition, TEM observation gives pictures of only local parts of the sample. This may be the reason why closed edges were observed in PC2800 plasma-fluorinated for $60 \mathrm{~min}$ as shown in Fig. 1(c). The increase in the surface disorder due to plasma-fluorination was found by Raman spectroscopy as shown in Table 3 as $R$ values (=peak intensity ratios of D-band to G-band in Raman spectra). $R$ value is a measure indicating the degree of surface disorder of carbon materials [52,53]. The increase in $R$ values was larger in PC2300 and PC2800 than in PC1860. Plasma-

Table 3

$R$ values $\left(=I_{\mathrm{D}} / I_{\mathrm{G}}\right)$ calculated from Raman shifts of petroleum cokes and plasmafluorinated samples

\begin{tabular}{lllll}
\hline $\begin{array}{l}\text { Plasma-fluorination } \\
\text { time }(\mathrm{min})\end{array}$ & \multicolumn{4}{l}{$R\left(=I_{\mathrm{D}} / I_{\mathrm{G}}\right)$} \\
\cline { 2 - 5 } & $\mathrm{PC}$ & $\mathrm{PC} 1860$ & $\mathrm{PC} 2300$ & $\mathrm{PC} 2800$ \\
\hline 0 & 1.30 & 0.45 & 0.15 & 0.11 \\
15 & - & 0.46 & 0.27 & 0.49 \\
30 & - & 0.59 & 0.43 & 0.36 \\
60 & 1.22 & 0.63 & 0.52 & 0.38 \\
\hline
\end{tabular}


(a)

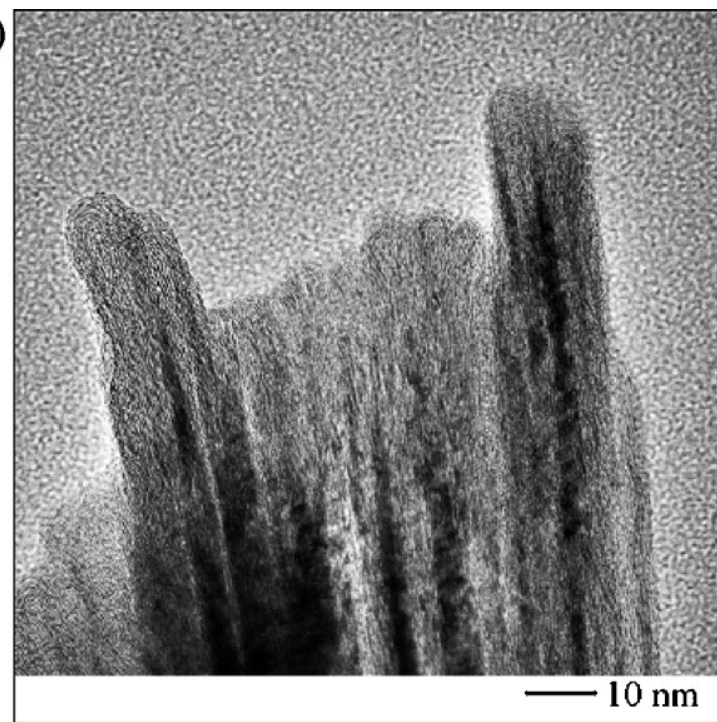

(b)

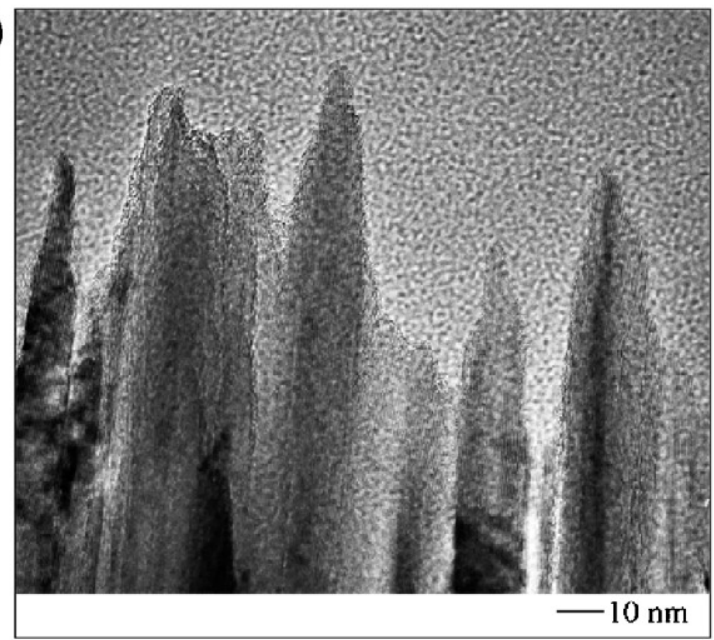

(c)

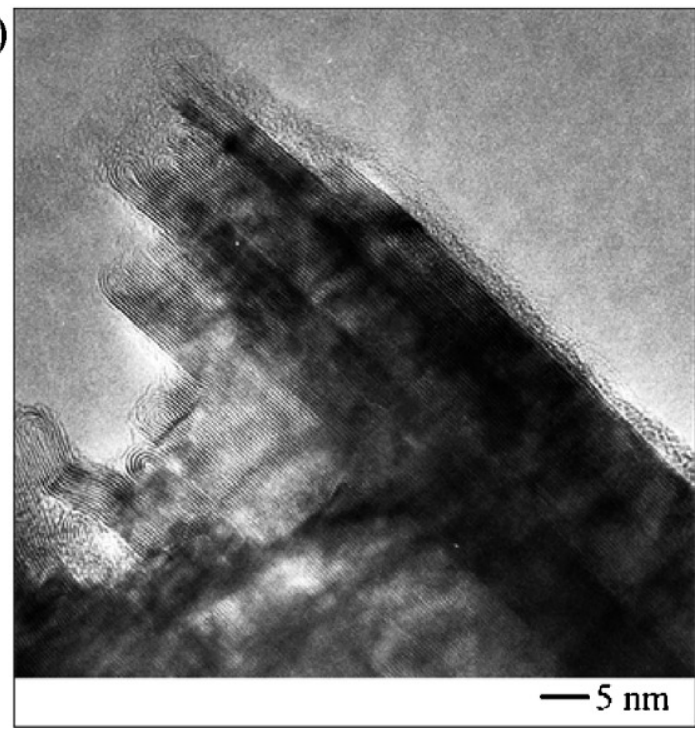

Fig. 1. Transmission electron microscopic images (TEM images) of PC2800 and those plasma-fluorinated for 15 and $60 \mathrm{~min}$. (a) PC2800, (b) 15 min-fluorinated PC2800, (c) 60 min-fluorinated PC2800.
Table 4

Specific surface areas of petroleum cokes and plasma-fluorinated samples

\begin{tabular}{lllll}
\hline Fluorination time $(\mathrm{min})$ & \multicolumn{4}{l}{ Surface area $\left(\mathrm{m}^{2} \mathrm{~g}^{-1}\right)$} \\
\cline { 2 - 5 } & PC & PC1860 & PC2300 & PC2800 \\
\hline 0 & 6.35 & 3.31 & 2.33 & 2.43 \\
15 & - & 2.77 & 2.21 & 2.15 \\
30 & - & 3.07 & 2.41 & 2.20 \\
60 & 4.40 & 2.66 & 2.05 & 1.77 \\
\hline
\end{tabular}

fluorination thus increases the surface disorder by destroying and opening the closed edge planes of graphitized petroleum cokes. BET surface area measurement indicated that the surface areas were somewhat decreased in most of the plasma-fluorinated samples due to surface etching effect by radical species produced in plasma as given in Table 4. Pore size distribution was also changed by plasma-treatment. Main change was the increase in surface meso-pores with diameter of $1.5-2 \mathrm{~nm}$ and decrease in those with diameter of $2-3 \mathrm{~nm}$.

\subsection{Electrochemical behavior of plasma-fluorinated petroleum cokes}

First coulombic efficiencies of PC1860 heat-treated at a medium temperature of $1860{ }^{\circ} \mathrm{C}$ were high values of 90.2 and $88.2 \%$ at 60 and $150 \mathrm{~mA} \mathrm{~g}^{-1}$, respectively. But those of PC2300 and PC2800 decreased to 71.9-70.0 and 65.4-63.6\% with increasing heat-treatment temperature, respectively $[37,38]$. The decrease in the first coulombic efficiencies for non-fluorinated PC2300 and PC2800 is attributed to the closure of edge plane caused during graphitization process [39]. The closed edge plane hinders the smooth formation of SEI by electrochemical decomposition of a small amount of EC.

Plasma-fluorination gave a good effect to the electrode performance of graphitized petroleum cokes, i.e. PC2300 and PC2800 as shown in Figs. 2-4. No positive effect was found for low crystalline PC and PC1860. Fig. 2 shows the cyclic voltammograms obtained for PC2800 and plasma-fluorinated samples. Similar cyclic voltammograms were obtained for PC2300 and plasma-fluorinated samples. A large cathodic current peak was found at ca. $0.6 \mathrm{~V}$ versus $\mathrm{Li} / \mathrm{Li}^{+}$at first cycle for non-fluorinated PC2800, indicating the electrochemical reduction of EC and subsequent formation of SEI. This cathodic peak was reduced with increasing plasma-treatment time as shown in Fig. 2. It means that SEI is formed by the decomposition of less amounts of EC. Fig. 3 shows charge/discharge potential curves obtained for PC2800 and those plasma-fluorinated for 15,30 and $60 \mathrm{~min}$. In consistency with the cyclic voltammograms, a potential plateau corresponding to the decomposition of $\mathrm{EC}$ was observed between 0 and $1 \mathrm{~V}$ at first cycle for non-fluorinated PC2800. The potential plateau between 0 and $1 \mathrm{~V}$ was clearly decreased by plasma-fluorination, which coincides well with the results obtained by cyclic voltammetry. Fig. 4 shows coulombic efficiencies for PC2300 and PC2800 as a function of cycle number. In the case of PC and PC1860, first coulombic efficiencies were not changed by 15 min plasma-treatment, slightly decreasing by 30 and 60 min treatments. As shown in Figs. 2-4, increase 


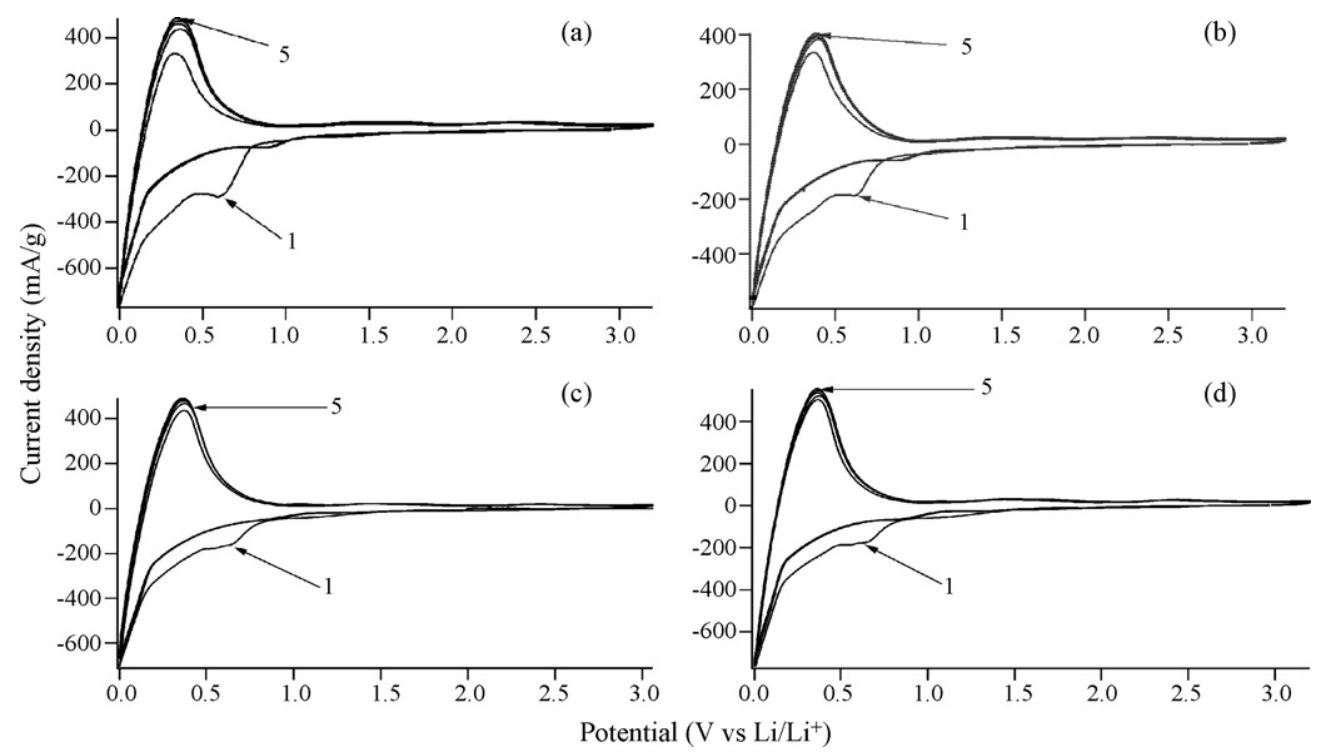

Fig. 2. Cyclic voltammograms for PC2800 and those plasma-fluorinated for 15, 30 and 60 min. (a) PC2800, (b) 15 min-fluorinated PC2800, (c) 30 min-fluorinated PC2800, (d) 60 min-fluorinated PC2800. 1: first cycle, 5: fifth cycle.
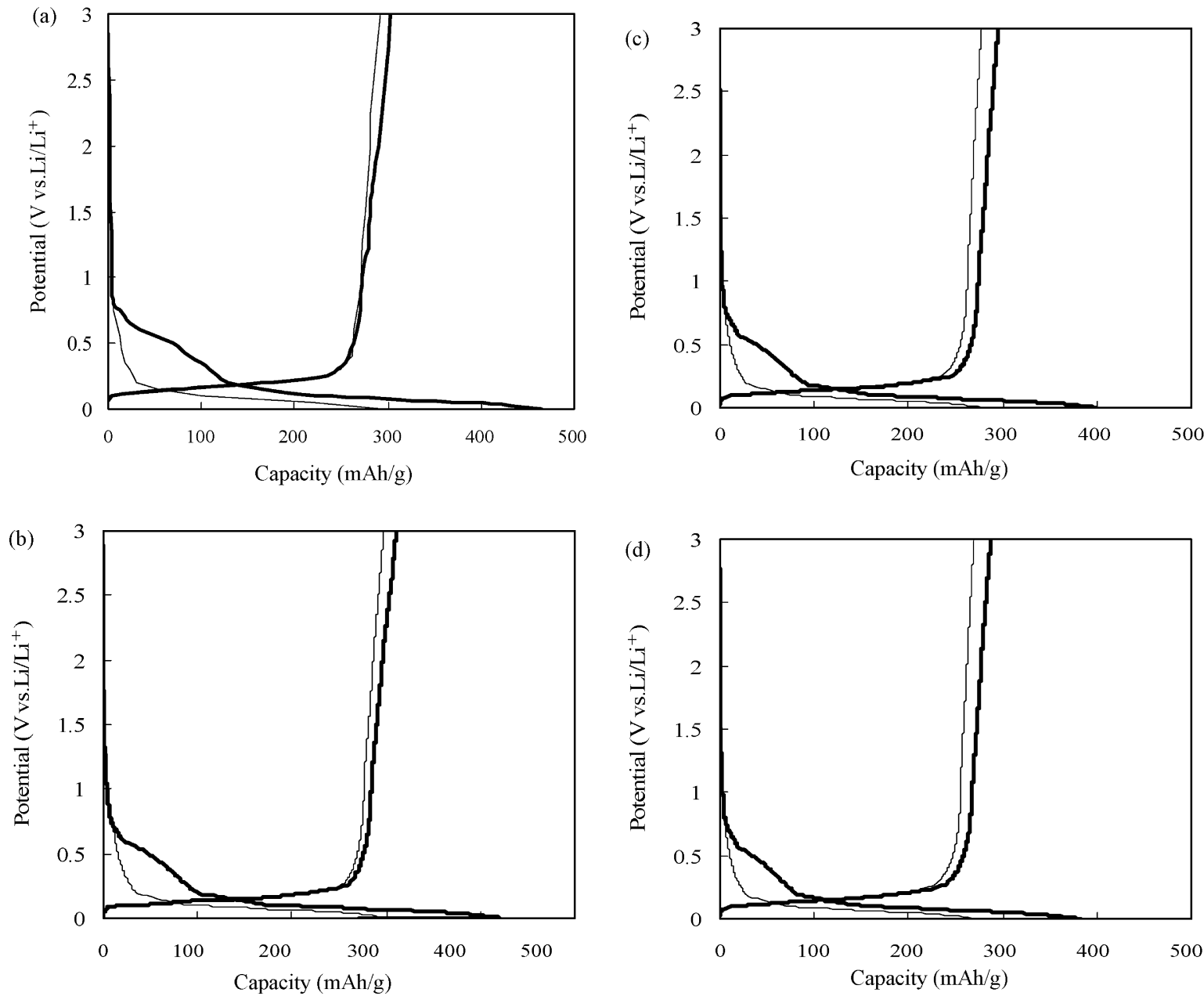

Fig. 3. Charge/discharge potential curves for PC2800 and those plasma-fluorinated for 15,30 and 60 min, obtained at $60 \mathrm{~mA} \mathrm{~g}^{-1}$. (a) PC2800, (b) $15 \mathrm{~min}$-fluorinated PC2800, (c) 30 min-fluorinated PC2800, (d) 60 min-fluorinated PC2800. (-) first cycle, (-- -) 10th cycle. 

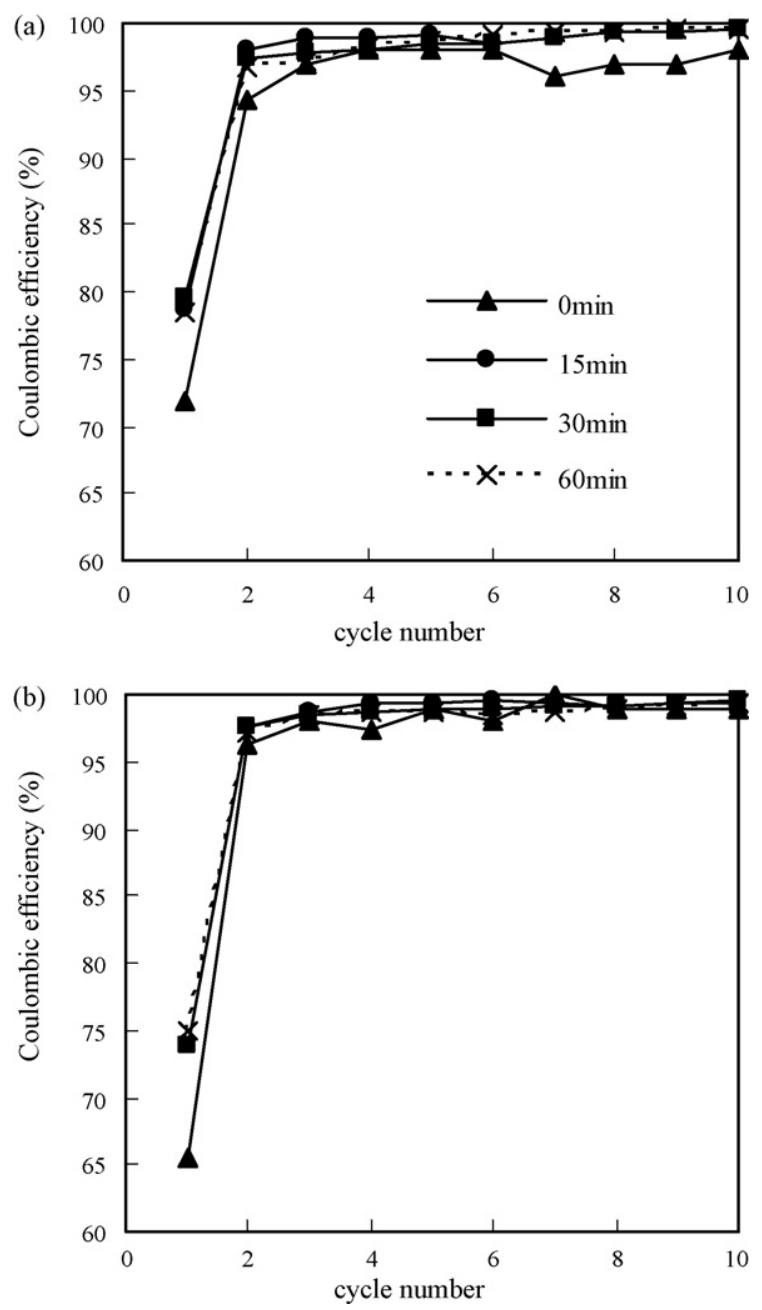

Fig. 4. Coulombic efficiencies for PC2300, PC2800 and those plasmafluorinated for 15,30 and $60 \mathrm{~min}$, obtained at $60 \mathrm{~mA} \mathrm{~g}^{-1}$ as a function of cycle number. (a) PC2300 and plasma-fluorinated samples, (b) PC2800 and

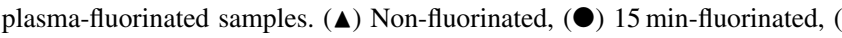
30 min-fluorinated, $(\times) 60$ min-fluorinated.

in the first coulombic efficiencies was found for graphitized PC2300 and PC2800. The increments of their first coulombic efficiencies were in the range of $6-8$ and $8-10 \%$ for $\mathrm{PC} 2300$ and PC2800 at $60 \mathrm{~mA} \mathrm{~g}^{-1}$, respectively. However, the charge capacities were not changed at $60 \mathrm{~mA} \mathrm{~g}^{-1}$ by the plasma-fluorination. Table 5 summarizes the results obtained for PC1860, PC2300 and PC2800 plasma-fluorinated for $30 \mathrm{~min}$ at $150 \mathrm{~mA} \mathrm{~g}^{-1}$. The increments in first coulombic efficiencies of PC2300 and

\section{Table 5}

First charge capacities and first coulombic efficiencies of petroleum cokes plasma-fluorinated for $30 \mathrm{~min}$ at $150 \mathrm{~mA} \mathrm{~g}^{-1}$

\begin{tabular}{llll}
\hline Sample & PC1860 & PC2300 & PC2800 \\
\hline First charge capacity $\left(\mathrm{mAh} \mathrm{g}^{-1}\right)$ & & & \\
$\quad$ Original & 184 & 210 & 210 \\
Plasma-fluorinated & 239 & 220 & 203 \\
First coulombic efficiency (\%) & & & \\
$\quad$ Original & 89.1 & 70.0 & 63.6 \\
Plasma-fluorinated & 85.4 & 78.0 & 72.5 \\
\hline
\end{tabular}

PC2800 were 8.0 and $8.9 \%$, respectively. In addition, first charge capacity of PC1860 was also increased by plasma-fluorination. As shown in Fig. 1, plasma-fluorination destroyed and removed the closed edge planes of graphitized petroleum cokes by radical reaction, increasing the surface disorder as given in Table 3 . The increase in the surface disorder would enable the easy formation of SEI by the decomposition of less amounts of EC as shown in Figs. 2 and 3, which leads to the increase in first coulombic efficiencies, i.e. decrease in irreversible capacities. Impedance measurement made on petroleum cokes heat-treated at 2100 and $2600{ }^{\circ} \mathrm{C}$ showed that charge transfer resistance was reduced by surface fluorination while resistance of SEI was increased [39]. The increase in the resistance of SEI may be due to formation of a fluoride such as LiF. Influence of surface fluorination on SEI formation is probably similar to the previous case in which petroleum cokes were fluorinated by $\mathrm{F}_{2}$ [39].

\section{Conclusions}

Effect of plasma-fluorination on the surface structure change and electrode performance of petroleum cokes has been investigated. Surface edge plane of oxygen containing petroleum coke is closed by carbon-carbon bond formation during the graphitization process. Closed edge planes of graphitized petroleum cokes gave a difficulty to smooth formation of SEI by the electrochemical decomposition of a small amount of EC, decreasing first coulombic efficiencies of PC2300 and PC2800 to 71.9-70.0 and $65.4-63.6 \%$, respectively $[37,38]$. To change the surface structure of petroleum cokes, plasma-fluorination was performed for 15, 30 and $60 \mathrm{~min}$ using $\mathrm{CF}_{4}$ gas. Fluorine contents obtained by elemental analysis were negligible except PC fluorinated for $60 \mathrm{~min}$. However, surface fluorine concentrations obtained by XPS were similar to those observed in the fluorination by $F_{2}$. It shows that only surface was fluorinated by plasma-fluorination. TEM observation of plasma-fluorinated PC2800 revealed that the closed edge plane was removed and opened by plasma-fluorination. BET surface areas were slightly decreased by surface etching effect. $R$ values calculated from two Raman shifts indicated that the surface disorder of heat-treated petroleum cokes was increased by plasma-treatment. Cyclic voltammograms obtained for PC2300 and PC2800 demonstrated that cathodic current peaks indicating the reduction of EC were significantly reduced by plasma-fluorination. The results of galvanostatic charge/discharge experiments coincided well with those obtained by cyclic voltammetry, showing that first coulombic efficiencies of PC2300 and PC2800 increased by $6-8$ and $8-10 \%$ at both 60 and $150 \mathrm{mAg}^{-1}$, respectively.

\section{Acknowledgement}

The present study was partly supported by a grant of the Frontier Research Project "Materials for the 21st Century—Materials Development for Environment, Energy and Information" (for 2002-2006 fiscal years) from Ministry of Education, Culture, Sports, Science and Technology. 


\section{References}

[1] T. Nakajima, H. Groult (Eds.), Fluorinated Materials for Energy Conversion, Elsevier, Oxford, 2005.

[2] T. Takamura, Bull. Chem. Soc. Jpn. 75 (2002) 21.

[3] Y.P. Wu, E. Rahm, R. Holze, Electrochim. Acta 47 (2002) 3491.

[4] Y.P. Wu, E. Rahm, R. Holze, J. Power Sources 114 (2003) 228.

[5] L.J. Ning, Y.P. Wu, S.B. Fang, E. Rahm, R. Holze, J. Power Sources 133 (2004) 229.

[6] T. Tsumura, A. Katanosaka, I. Souma, T. Ono, Y. Aihara, J. Kuratomi, M. Inagaki, Solid State Ionics 135 (2000) 209.

[7] H. Wang, M. Yoshio, J. Power Sources 93 (2001) 123.

[8] S. Soon, H. Kim, S.M. Oh, J. Power Sources 94 (2001) 68.

[9] M. Yoshio, H. Wang, K. Fukuda, Y. Hara, Y. Adachi, J. Electrochem. Soc. 147 (2000) 1245.

[10] H. Wang, M. Yoshio, T. Abe, Z. Ogumi, J. Electrochem. Soc. 149 (2002) A499.

[11] M. Yoshio, H. Wang, K. Fukuda, T. Umeno, N. Dimov, Z. Ogumi, J. Electrochem. Soc. 149 (2002) A1598.

[12] Y.-S. Han, J.-Y. Lee, Electrochim. Acta 48 (2003) 1073.

[13] Y. Ohzawa, M. Mitani, T. Suzuki, V. Gupta, T. Nakajima, J. Power Sources 122 (2003) 153.

[14] Y. Ohzawa, Y. Yamanaka, K. Naga, T. Nakajima, J. Power Sources 146 (2005) 125.

[15] R. Takagi, T. Okubo, K. Sekine, T. Takamura, Denki Kagaku 65 (1997) 333.

[16] T. Takamura, K. Sumiya, J. Suzuki, C. Yamada, K. Sekine, J. Power Sources 81/82 (1999) 368.

[17] Y. Wu, C. Jiang, C. Wan, E. Tsuchida, Electrochem. Commun. 2 (2000) 626.

[18] S.-S. Kim, Y. Kadoma, H. Ikuta, Y. Uchimoto, M. Wakihara, Electrochem. Solid-State Lett. 4 (2001) A109.

[19] J.K. Lee, D.H. Ryu, J.B. Ju, Y.G. Shul, B.W. Cho, D. Park, J. Power Sources 107 (2002) 90.

[20] I.R.M. Kottegoda, Y. Kadoma, H. Ikuta, Y. Uchimoto, M. Wakihara, Electrochem. Solid-State Lett. 5 (2002) A275.

[21] I.R.M. Kottegoda, Y. Kadoma, H. Ikuta, Y. Uchimoto, M. Wakihara, J. Electrochem. Soc. 152 (2005) A1595.

[22] E. Peled, C. Menachem, D. Bar-Tow, A. Melman, J. Electrochem. Soc. 143 (1996) L4.

[23] J.S. Xue, J.R. Dahn, J. Electrochem. Soc. 142 (1995) 3668.

[24] M. Hara, A. Satoh, N. Tamaki, T. Ohsaki, Tanso 165 (1994) 261.

[25] Y. Ein-Eli, V.R. Koch, J. Electrochem. Soc. 144 (1997) 2968.

[26] Y. Wu, C. Jiang, C. Wan, E. Tsuchida, J. Mater. Chem. 11 (2001) 1233.

[27] Y.P. Wu, C. Jiang, C. Wan, Holze, Electrochem. Commun. 4 (2002) 483.

[28] Y. Wu, C. Jiang, C. Wan, R. Holze, J. Power Sources 111 (2002) 329.
[29] Y.P. Wu, C. Jiang, C. Wan, R. Holze, J. Appl. Electrochem. 32 (2002) 1011.

[30] T. Nakajima, M. Koh, R.N. Singh, M. Shimada, Electrochim. Acta 44 (1999) 2879.

[31] V. Gupta, T. Nakajima, Y. Ohzawa, H. Iwata, J. Fluorine Chem. 112 (2001) 233.

[32] T. Nakajima, V. Gupta, Y. Ohzawa, H. Iwata, A. Tressaud, E. Durand, J. Fluorine Chem. 114 (2002) 209.

[33] T. Nakajima, V. Gupta, Y. Ohzawa, M. Koh, R.N. Singh, A. Tressaud, E. Durand, J. Power Sources 104 (2002) 108.

[34] T. Nakajima, V. Gupta, Y. Ohzawa, H. Iwata, A. Tressaud, E. Durand, Mol. Cryst. Liq. Cryst. 388 (517) (2002) 103.

[35] H. Groult, T. Nakajima, L. Perrigaud, Y. Ohzawa, H. Yashiro, S. Komaba, N. Kumagai, J. Fluorine Chem. 126 (2006) 1111

[36] K. Matsumoto, J. Li, Y. Ohzawa, T. Nakajima, Z. Mazej, B. Žemva, J. Fluorine Chem. 127 (2006) 1383.

[37] T. Nakajima, J. Li, K. Naga, K. Yoneshima, T. Nakai, Y. Ohzawa, J. Power Sources 133 (2004) 243.

[38] J. Li, K. Naga, Y. Ohzawa, T. Nakajima, A.P. Shames, A.I. Panich, J. Fluorine Chem. 126 (2005) 265.

[39] J. Li, Y. Ohzawa, T. Nakajima, H. Iwata, J. Fluorine Chem. 126 (2005) 1028.

[40] K. Naga, T. Nakajima, Y. Ohzawa, B. Žemva, Z. Mazej, H. Groult, J. Electrochem. Soc. 154 (2007) A347.

[41] S. Kuwabata, N. Tsumura, S. Goda, C.R. Martin, H. Yoneyama, J. Electrochem. Soc. 145 (1998) 1415

[42] M. Gaberscek, M. Bele, J. Drofenik, R. Dominko, S. Pejovnik, Electrochem. Solid State Lett. 3 (2000) 171.

[43] J. Drofenik, M. Gaberscek, R. Dominko, M. Bele, S. Pejovnik, J. Power Sources 94 (2001) 97.

[44] M. Bele, M. Gaberscek, R. Dominko, J. Drofenik, K. Zupan, P. Komac, K. Kocevar, I. Musevic, S. Pejovnik, Carbon 40 (2002) 1117.

[45] M. Gaberscek, M. Bele, J. Drofenik, R. Dominko, S. Pejovnik, J. Power Sources 97/98 (2001) 67.

[46] B. Veeraraghavan, J. Paul, B. Haran, B. Popov, J. Power Sources 109 (2002) 377.

[47] M. Holzapfel, H. Buqa, F. Krumeich, P. Novak, F.M. Petrat, C. Veit, Electrochem. Solid-State Lett. 8 (2005) A516.

[48] K. Moriguchi, S. Munetoh, M. Be, M. Yonemura, K. Kamei, A. Shintani, A. Omaru, M. Nagamine, J. Appl. Phys. 88 (2000) 6369.

[49] S. Rozen, C. Gal, Tetrahedron Lett. 25 (1984) 449.

[50] S. Rozen, C. Gal, J. Fluorine Chem. 27 (1985) 143

[51] M. Koh, H. Yumoto, H. Higashi, T. Nakajima, J. Fluorine Chem. 97 (1999) 239.

[52] F. Tuinstra, J.L. Koenig, J. Chem. Phys. 53 (1970) 1126.

[53] D.S. Knight, W.B. White, J. Mater. Res. 4 (1989) 385. 